\title{
Incidence of Induced Abortion by Age and State, Mexico, 2009: New Estimates Using a Modified Methodology
}

\section{By Fatima \\ Juarez and \\ Susheela Singh}

Fatima Juarez is professor of demography, El Colegio de Mexico, Mexico City, and senior fellow,

Guttmacher Institute,

New York. Susheela Singh is vice president for research,

Guttmacher Institute.

\begin{abstract}
CONTEXT: Because abortion laws in Mexico, which are generally highly restrictive, are determined by individual states, state-level data are essential for policymakers to make informed decisions. In addition, age-specific abortion estimates are needed, given societal concern about young women's risk for unwanted pregnancy and abortion.
\end{abstract}

METHODS: The Abortion Incidence Complications Method, an established approach designed to obtain national and broad regional estimates, was extended to produce for the first time estimates for age-groups and states. Data included government statistics on postabortion patients and health professionals' estimates concerning abortion complications. States were classified into six regions according to level of development.

RESULTS: In 2009, the abortion rate in Mexico was 38 per 1,000 women aged 15-44. The rate was 54 per 1,000 in Region 1 (Mexico City), the most developed region; 35-41 per 1,000 in Regions 2, 3 and 4, which are moderately developed; and 26-27 in Regions 5 and 6, which are the least developed. States'rates of abortion incidence and treatment for induced abortion complications were generally consistent with development level, although exceptions emerged. Age-specific abortion rates peaked among women aged 20-24 and then steadily declined with age; this pattern was observed nationally, regionally and in most states.

CONCLUSION: Extension of the Abortion Incidence Complications Method to obtain state- and age-specific data is feasible. Unsafe abortion is common in all states of Mexico, especially among women aged 15-24, suggesting a need for improved family planning and postabortion services.

International Perspectives on Sexual and Reproductive Health, 2012, 38(2):58-67, doi: 10.1363/3805812

Unsafe abortion-defined by the World Health Organization as a procedure for termination of an unintended pregnancy performed by people lacking the necessary skills, in an environment that does not conform to minimum medical standards, or both ${ }^{1}$-continues to be an important public health problem. It negatively affects women, their families, public health systems and, ultimately, economic productivity. Addressing the issue of unsafe abortion is an ongoing challenge in Mexico, where the lack of recent national estimates, and especially of state- and age-specific estimates, contributes to denial of the gravity of the problem and its consequences.

Among the most important constraints to measuring the incidence of abortion are the stigma attached to the procedure and abortion's illegality, which result in underreporting by both women and providers, even when they are directly questioned. ${ }^{2}$ Because of these difficulties, indirect estimation methodologies are necessary; unfortunately, most of these approaches have strong limitations that result in biased estimates. One widely used method that provides solid estimates is the Abortion Incidence Complications Method, which has been applied to about 15 developing countries, including several in Latin America. It is a useful approach in settings where abortion is highly restricted, or where it is permitted under broad criteria but, for various reasons, is performed under unsafe conditions. ${ }^{3-7}$
The Abortion Incidence Complications Method has been applied to Mexico in two previous studies, yielding estimates for 1990 at the national level and for 2006 both for the country as a whole and for four large geographic areas (North, Central, South/East and Mexico City). ${ }^{5,6}$ In the current analysis, we adapt this method to generate estimates, by both state and age-group, of the incidence of abortion and of treatment for postabortion complications in Mexico in 2009. This information is needed to inform policies and programs in Mexico, where induced abortion is legally restricted in all areas except Mexico City (Federal District), which in 2007 legalized first-trimester procedures. $^{8}$

\section{DATA AND METHODS}

\section{Data Sources}

We used two data sources to estimate abortion incidence and related morbidity: government hospital data from the Mexican Ministry of Health and a survey of key informants who were knowledgeable about abortion provision in Mexico. ${ }^{5}$

- Hospital data. The Ministry of Health's National System of Health Information (Sistema Nacional de Información en Salud) provided data on the number of women treated for abortion complications in the various subsystems of public-sector hospitals in 2009 (the most recent year for 
which data were available at the time of the analysis).* The data fell into three categories: discharge data on inpatients, available for each subsystem of the country's health system; ${ }^{9}$ data on outpatient care,${ }^{10}$ also available for each subsystem; and data on emergency room patients, available only for the largest subsystem (Secretaría de Salud). ${ }^{11}$ These data required some adjustments, which are explained in greater detail below; briefly, we needed to account for cases of induced abortion that were not accurately coded as such, and to remove cases of spontaneous abortions (miscarriages), because the hospital data do not accurately differentiate between spontaneous and induced abortions.

The data set on inpatients included only women with abortion complications who stayed in a facility overnight. ${ }^{\dagger}$ Because the Abortion Incidence Complications Method has not previously been used to calculate state-level and age-specific abortion estimates for Mexico, we conducted detailed sensitivity analyses to ascertain the quality of the data set's input variables-patient's age, the state where the abortion complications were treated, and the ICD-10 (International Classification of Disease, 10th revision) code-for each health subsystem. We examined trends and patterns by age and state from 2005 to 2009 (the most recent period for which data were available electronically at the time of analysis) to identify any erratic fluctuations, which may indicate incomplete or poor quality data. A previous study that examined hospital information from 2000-2006 concluded that those data were of good quality. ${ }^{12}$ The new analyses showed stable patterns and trends in the number of women with abortion complications by ICD code, health system, state and patient's age-an indication of good data quality. The distribution of women in each state by age was also stable during this period.

To estimate the number of women treated for abortion complications as outpatients, we used a separate database containing information on the total number of women with postabortion complications treated as inpatients and outpatients by each health subsystem in each state. The number of outpatients was obtained by subtracting the number of inpatients from this total. To estimate the number of cases for each age-group, we assumed that, within each state, outpatients had the same age distribution as inpatients.

The final hospital data set concerned emergency room patients. Collection of information on all emergency cases, including postabortion patients, started only recently; data by age were available only for 2007-2009, and only for one health subsystem, the Secretaría de Salud. A sensitivity analysis indicated that reporting improved steadily between 2007 and 2009. The Secretaría de Salud is Mexico's largest hospital system, and its inpatient postabortion caseload accounted for 76\% of the country's cases in 2009 . To estimate the number of emergency room abortion cases for other health subsystems, we first calculated for the Secretaría de Salud the ratio of emergency room cases $(29,532)$ to inpatient cases $(103,898)$, which is equivalent to 28.4 emergency cases per 100 inpatient cases. ${ }^{\ddagger}$ Rather than use this ratio to generate estimates for other health subsystems, we made a conservative assumption and applied half of the value of the ratio. The ratio was reduced because women served by the Secretaría de Salud are poorer, less educated and more likely to use emergency room services than women served by other health subsystems, who generally have better access to health care, and are more likely to prevent unplanned pregnancies, seek services in a timely manner and turn to private doctors. ${ }^{13}$ We assumed that the age distribution of women seeking emergency care from other health systems was the same as that for the Secretaría de Salud.

Overall, we estimated that 203,027 women were treated for complications of induced or spontaneous abortion in all public-sector health systems in 2009. Of these, 139,846 (69\%) were treated as inpatients, 28,542 (14\%) as outpatients, and 34,639 (17\%) in emergency rooms $(29,532$ cases from the Secretaría de Salud and 5,107 from other health subsystems).

- Health Professionals Survey data. The 2007 Health Professionals Survey was designed to assess the conditions under which women obtain induced abortions and to explore the extent of misoprostol use. Through a structured questionnaire, information was collected from key informants with extensive knowledge of clandestine abortion in Mexico. Respondents provided estimates for a variety of measures. These included the percentage distribution of Mexican women who have an abortion, according to the method of abortion (misoprostol or other); the "other" abortions were further broken down by provider type. Respondents also estimated the likelihood that women who have an abortion experience complications requiring medical care, again by method and provider type, and the likelihood that women with complications obtain care in a public- or private-sector health facility. A total of 132 informants from five states and the Federal District were interviewed; about two-thirds were medical providers, while the rest were nonmedical experts (social workers, researchers, policymakers, advocates and public administrators).

\section{Adjustment to ICD-10 Codes}

The ICD-10 diagnostic codes that are used to identify women treated for abortion complications are codes $\mathrm{O} 00$ to O08. The Abortion Incidence Complications Method removes cases caused solely by biological factors-those

*These data cover all of the main subsystems: Secretaría de Salud, Instituto Mexicano del Seguro Social (IMSS), Instituto de Seguridad y Servicios Sociales de los Trabajadores del Estado, Petróleos Mexicanos, Secretaría de la Defensa Nacional, Secretaría de Marina and IMSS Oportunidades.

+Under the current Mexican definition of discharged hospital patients, the database includes only patients who had "camas censables" (hospital beds with at least one overnight stay).

‡The count of emergency cases excluded women who were treated in the emergency room but subsequently hospitalized (and therefore counted as inpatients).

$\S$ The five states were Baja California, Chiapas, Guanajuato, Veracruz and Yucatán. 
coded as $\mathrm{O00}$ (ectopic pregnancy), O01 (hydatidiform mole) or O02 (other abnormal products of conception)as they are unrelated to spontaneous or induced abortion. However, in recent years, specialists in obstetrics and gynecology have observed that incorrect use of misoprostol to induce abortion can result in cases that are diagnosed and classified as codes O02.0 (blighted ovum and nonhydatidiform mole) or O02.1 (retained products of conception or "missed abortion"). ${ }^{14}$ Thus, some proportion of cases receiving these two subcodes should be classified as induced abortion cases. We propose that the Abortion Incidence Complications Method be improved by adjusting for the proportion of cases incorrectly coded as 002 . We obtained an estimate of this proportion by surveying 16 gynecologists who had extensive experience in treating abortion complications. By averaging their responses, we estimated that $35 \%$ of cases coded as 002.0 and $55 \%$ of cases coded as 002.1 represent complications of induced abortion. As a result, our estimate of the number of induced and spontaneous abortions includes 15,047 cases that received these codes; they represent $7 \%$ of the 203,027 induced and spontaneous abortions in 2009.

\section{Removal of Spontaneous Abortion Cases}

The next step is to estimate the number of women treated for complications of spontaneous abortion and remove them from the count of women treated for induced or spontaneous abortion. Hospital data typically do not accurately distinguish between induced and spontaneous abortions, partly because the symptoms of the two are often similar and partly because facilities are reluctant to expose patients to the potential legal repercussions of having had an illegal abortion. We used clinical data on the average biological pattern of spontaneous pregnancy loss ${ }^{15,16}$ to indirectly estimate the proportions of women who experience late miscarriage (i.e., at 13-21 weeks' gestation), are likely to require treatment at a hospital and, if they receive care, would be included in our count of postabortion patients. ${ }^{*}$ We assumed that women who experience spontaneous pregnancy loss in the first trimester generally do not need hospital care, and that if they do obtain medical care, they visit primary health care centers or private physicians (and thus are not included in the hospital data). Using this approach, we estimated that the number of late miscarriages equaled $3.41 \%$ of all live births. A further adjustment was needed because only a fraction of women who need hospital care for the treatment of late spontaneous pregnancy loss obtain such services; we assumed that this proportion was the same as the proportion of births delivered at government facilities (67\%, according to estimates from the most recent available information). ${ }^{17}$ Therefore, we estimated that 44,022 women were treated in Mexico for complications of spontaneous abortion, which in turn means that 159,005 women were hospitalized for compli-

*Pregnancy losses after 21 weeks' gestation were not included because they are classified as fetal deaths rather than abortions. cations of induced abortion. We used the same process to generate estimates for each state and age-group.

\section{Calculation of Multipliers}

In estimating the incidence of abortion using hospital records of abortion complications, we need to calculate a multiplier that accounts for women who did not have complications, or who had complications but did not obtain treatment; this can be done using data from the Health Professionals Survey. In general, the safer abortion services are, the higher the multiplier, because for every woman receiving treatment, many more have abortions that do not result in complications requiring medical care. Likewise, the less safe abortion services are, the lower the multiplier, because a higher proportion of women will have serious complications that require care. The multiplier also accounts for the accessibility of health facilities and for women's attitudes toward seeking care from facilities. In areas where facilities are easily accessible, the proportion of women with complications who receive treatment will be higher. In poor or underdeveloped regions, by contrast, some of the most seriously affected women may not get the treatment they need. The likelihood that women will obtain care will also be low in places where the stigma surrounding abortion is stronger, which may lead providers to treat women poorly and, in turn, cause women to have negative attitudes toward health facilities. Calculation of multipliers is described in detail elsewhere., ${ }^{5,12}$

Although the Health Professionals Survey data are from 2007-two years before the abortion complications data were collected-we do not believe that the discrepancy had any meaningful effect on our estimates, as it is unlikely that conditions of abortion provision, degree of risk from abortion procedures and access to health services changed substantially during this brief period. We consider use of the Health Professionals Survey data acceptable even in the case of Mexico City, where first-trimester pregnancy termination was decriminalized in April 2007. ${ }^{8}$ Because the law had been changed only recently (allowing little time for expansion of services or reductions in stigma), the number of legal public-sector abortions recorded in Mexico City in $2009(16,475)^{18}$ was insignificant compared with the 165,455 abortions estimated to have taken place in $2006 ;^{5}$ this suggests that the multiplier for Mexico City would have changed very little, if at all, since 2006.

The Health Professionals Survey was designed to generate multipliers for four major areas of the country that differ broadly in their socioeconomic status and conditions of abortion provision. These areas are Mexico City, the most developed of the four, which has the safest abortion services (multiplier, 10.5); the North, which has the second-highest level of economic development (4.9); the Central area, which is moderately developed but less affluent than the North (6.7); and the South/East area, the least developed of the four (5.0)., . 12 We applied each multiplier to every state within the relevant area. In the absence of information to the contrary, we assumed that each state's 
multiplier applied to women of all ages.

In estimating state-specific rates, we made two modifications to the protocol used in the 2006 study (which provided estimates for the four major areas but not for individual states). The first concerns the multiplier used for the North area.* Although the earlier study used a single multiplier for all states in this area, we have used two multipliers. This is because the multiplier that we estimated using information from Health Professionals Survey participants in the North (all of whom lived in the state of Baja California) was much lower (4.9) than would be expected on the basis of its development level; for example, its multiplier is smaller than that for the Central area (6.7), which is markedly less developed than the North. The multiplier of 4.9 appears plausible for the northern states (such as Baja California) that border the United States, because Health Professionals Survey respondents likely based their estimates on abortions performed in Mexico, and did not take into account the safe procedures some women likely obtained in the United States. Thus, the abortions reported to be performed in these border states would likely be higher risk procedures, which means that the proportion of women needing treatment for complications would have been relatively high, and the multiplier relatively low. However, this multiplier is implausibly low for the rest of the northern states, from which travel to the United States for abortion is rare. In these states, which have a welldeveloped health care infrastructure and good economic conditions, access to low-risk (albeit clandestine) abortion is likely to be widespread, and we therefore expect the multiplier to be higher than the overall estimate for the North area. As a result, we assumed that the multiplier for the Central area applies to the states in the North that do not border the United States.

The second modification concerns the estimates of the abortion rate for Mexico City and neighboring Mexico State (part of which is within the Mexico City metropolitan area). Because women who live in the sections of Mexico State that border Mexico City sometimes obtain care in Mexico City hospitals, the 2006 study included women in these areas in the base population of Mexico City in calculations of the abortion rate. ${ }^{5}$ However, the bias caused by

\footnotetext{
*The area denoted as North includes some of the country's most developed states; most states in this area are located in the northern part of the country, but some are in the center. The North consists of Aguascalientes, Baja California, Baja California Sur, Chihuahua, Coahuila, Colima, Jalisco, Mexico, Nuevo León, Sonora and Tamaulipas.

†Before deciding to merge data for the two jurisdictions, we evaluated and rejected alternative approaches of accounting for women in Mexico State obtaining care in Mexico City (e.g., assigning to the base population of Mexico City certain subgroups of Mexico State residents, such as those who lived closest to the city or had good access by subway or other public transportation).

¥The index, known as the Índice de marginación, is based on the following variables: percentage of the population aged 15 or older that is illiterate; percentage of the population aged 15 or older that has not completed primary school; percentages of inhabitants living in households without drainage or an exclusive toilet, without electricity, without drinkable water, with some level of crowdedness and with an earthen floor; percentage of the population living in localities with fewer than 5,000 inhabitants; and percentage of the working population paid less than two times the minimum salary.
}

\begin{tabular}{|c|c|c|c|c|}
\hline Year & $\begin{array}{l}\text { No. of women } \\
\text { treated for } \\
\text { abortion } \\
\text { complications* }\end{array}$ & $\begin{array}{l}\text { Abortion } \\
\text { treatment rate* }\end{array}$ & $\begin{array}{l}\text { No.of } \\
\text { abortions }\end{array}$ & $\begin{array}{l}\text { Abortion } \\
\text { rate }\end{array}$ \\
\hline 1990 & 106,620 & 5.4 & 533,098 & 25.1 \\
\hline 2006 & 149,677 & 5.7 & 874,747 & 33.3 \\
\hline 2006 (revised) $^{* *}$ & 149,514 & 5.7 & 976,495 & 37.2 \\
\hline 2009 & 159,005 & 5.9 & $1,025,669$ & 38.0 \\
\hline
\end{tabular}

*In the previously published estimates for 2006 (reference 5), these measures were denoted as "No. of women hospitalized for complications of induced abortion" and "Induced abortion hospitalization rate." **Recalculated using 2009 methodology. Notes: Abortion treatment rate is the number of women treated for abortion complications per 1,000 women aged 15-44. Abortion rate is the number of abortions per 1,000 women aged 15-44. Sources: 1990 and 2006 data-reference 5.

this adjustment became evident when abortion rates were calculated for Mexico State using this approach, as the resulting estimates were implausibly high. Because it does not appear possible to accurately separate out the number of hospitalized postabortion patients and the size of the base population for Mexico City from those for Mexico State, we concluded that the only acceptable solution was to merge for these two areas all input measures used to calculate the abortion rate (i.e., multipliers and numbers of abortion complications, births and women). ${ }^{\dagger}$

\section{Regions and Level of Development}

In countries undergoing a fertility transition, such as Mexico, the desire for smaller families and for precise control of the timing of births is greater in more developed regions than in less developed ones. ${ }^{19,20}$ However, at the societal level, these desires tend to precede the widespread adoption of contraception, and for a time the prevalence of effective contraceptive use may fall short of the levels necessary to allow women to achieve their reproductive preferences. As a result, the incidence of unintended pregnancy-and thus of abortion-may be greater in more developed regions than in those that are less developed. We hypothesize that this is the case in Mexico.

Thus, we calculated regional estimates of abortion incidence by development level. We classified states into six regions using an official index of states' level of development; ${ }^{\ddagger 21}$ the index included indicators of household ame-

TABLE 2. Selected measures related to induced abortion treatment rate and induced abortion rate, Mexico, by region, 2009

\begin{tabular}{lcllll} 
Region & $\begin{array}{l}\text { No.of } \\
\text { women aged } \\
\text { 15-44 }\end{array}$ & $\begin{array}{l}\text { No.of women } \\
\text { treated for } \\
\text { abortion } \\
\text { complications }\end{array}$ & $\begin{array}{l}\text { Abortion } \\
\text { treatment } \\
\text { rate }\end{array}$ & $\begin{array}{l}\text { No.of } \\
\text { abortions }\end{array}$ & $\begin{array}{l}\text { Abortion } \\
\text { rate }\end{array}$ \\
\hline All & $\mathbf{2 6 , 9 9 1 , 7 2 5}$ & $\mathbf{1 5 9 , 0 0 5}$ & $\mathbf{5 . 9}$ & $\mathbf{1 , 0 2 5 , 6 6 9}$ & $\mathbf{3 8 . 0}$ \\
Region 1 & $2,250,126$ & 14,825 & 6.7 & 122,455 & 54.4 \\
Region 2 & $11,616,226$ & 73,022 & 6.3 & 470,612 & 40.5 \\
Region 3 & $3,645,957$ & 22,775 & 6.2 & 145,394 & 39.9 \\
Region 4 & $4,262,309$ & 22,339 & 5.2 & 150,645 & 35.3 \\
Region 5 & $2,437,626$ & 11,766 & 4.8 & 64,617 & 26.5 \\
Region 6 & $2,779,481$ & 14,278 & 5.1 & 71,946 & 25.9 \\
\hline
\end{tabular}

Notes: Abortion treatment rate is the number of women treated for abortion complications per 1,000 women aged 15-44. Abortion rate is the number of abortions per 1,000 women aged 15-44. 


\begin{tabular}{|c|c|c|c|c|}
\hline Region and state & $\begin{array}{l}\text { No.of women } \\
\text { treated for } \\
\text { abortion } \\
\text { complications }\end{array}$ & $\begin{array}{l}\text { Abortion } \\
\text { treatment } \\
\text { rate }\end{array}$ & $\begin{array}{l}\text { No.of } \\
\text { abortions }\end{array}$ & $\begin{array}{l}\text { Abortion } \\
\text { rate }\end{array}$ \\
\hline All & 159,005 & 5.9 & $1,025,669$ & 38.0 \\
\hline \multicolumn{5}{|l|}{ Region 1} \\
\hline Federal District & 14,825 & 6.7 & 122,455 & 54.4 \\
\hline \multicolumn{5}{|l|}{ Region 2} \\
\hline Aguascalientes & 1,975 & 6.8 & 13,331 & 46.0 \\
\hline Baja California Sur & 1,425 & 10.2 & 6,943 & 49.9 \\
\hline Baja California & 4,649 & 5.9 & 22,641 & 28.9 \\
\hline Chihuahua & 3,583 & 4.4 & 17,465 & 21.5 \\
\hline Coahuila & 5,885 & 9.1 & 28,715 & 44.6 \\
\hline Colima & 1,119 & 7.5 & 7,542 & 50.3 \\
\hline Jalisco & 10,581 & 6.1 & 71,332 & 40.8 \\
\hline México & 25,527 & 6.7 & 205,613 & 54.4 \\
\hline Nuevo León & 3,932 & 3.6 & 19,159 & 17.3 \\
\hline Sonora & 4,516 & 7.5 & 21,993 & 36.7 \\
\hline Tamaulipas & 5,562 & 7.0 & 27,059 & 34.0 \\
\hline Morelos & 2,397 & 5.8 & 16,185 & 38.8 \\
\hline Quintana Roo & 1,871 & 5.2 & 12,634 & 35.3 \\
\hline \multicolumn{5}{|l|}{ Region 3} \\
\hline Durango & 2,491 & 6.6 & 16,796 & 44.3 \\
\hline Guanajuato & 7,365 & 5.6 & 49,645 & 38.1 \\
\hline Nayarit & 1,510 & 6.4 & 10,203 & 43.6 \\
\hline Querétaro & 2,913 & 6.4 & 19,643 & 43.4 \\
\hline Sinaloa & 4,373 & 6.8 & 21,315 & 33.4 \\
\hline Tlaxcala & 1,521 & 5.2 & 10,251 & 34.8 \\
\hline Zacatecas & 2,602 & 7.6 & 17,541 & 51.1 \\
\hline \multicolumn{5}{|l|}{ Region 4} \\
\hline Campeche & 1,152 & 5.6 & 7,769 & 37.6 \\
\hline Michoacán & 5,844 & 5.9 & 39,410 & 39.5 \\
\hline Puebla & 6,650 & 4.7 & 44,849 & 31.4 \\
\hline San Luis Potosí & 2,606 & 4.3 & 17,561 & 28.6 \\
\hline Tabasco & 4,680 & 8.7 & 31,580 & 58.9 \\
\hline Yucatán & 1,407 & 2.9 & 9,476 & 19.7 \\
\hline \multicolumn{5}{|l|}{ Region 5} \\
\hline Hidalgo & 3,098 & 5.0 & 20,899 & 33.8 \\
\hline Veracruz & 8,668 & 4.8 & 43,718 & 24.0 \\
\hline \multicolumn{5}{|l|}{ Region 6} \\
\hline Chiapas & 5,754 & 5.1 & 29,006 & 25.5 \\
\hline Guerrero & 3,807 & 5.0 & 19,185 & 25.2 \\
\hline Oaxaca & 4,717 & 5.4 & 23,755 & 27.0 \\
\hline
\end{tabular}

nities and services, educational attainment and income. Regions were numbered in order of decreasing level of development, such that Region 1 is the most developed and Region 6 the least.* $^{*}$

\section{RESULTS}

\section{Trends in Abortion Incidence}

Applying the multipliers for each state and each age-group to the number of women treated for induced abortion complications yielded an estimate of 1,025,669 induced abortions performed in Mexico in 2009-almost twice the number performed in 1990 (Table 1, page 61). During this period, the abortion rate rose from 25 to 38 per 1,000 women aged $15-44$, an increase of $51 \%$, or $2.7 \%$ annually.

In previous research, we found that 874,747 abortions were performed in Mexico in 2006, equivalent to an abortion rate of 33 per $1,000 .^{5}$ To assess the impact of our methodological improvements on our estimates, we applied the 2009 methodology to the 2006 data. The new methodology yielded a somewhat higher abortion rate of 37 per 1,000 for 2006. This rate is only 2.1\% lower than that for 2009, indicating that very little change in abortion incidence occurred during that time.

We also assessed the impact of our second important methodological change-combining Mexico City with the bordering Mexico State to take into account women's traveling across state lines for postabortion care. Applying the 2009 methodology to 2006 data yielded a rate of 55 per 1,000 women for Mexico City, almost identical to the 2009 rate of 54, indicating essentially no change in the city's abortion rate (not shown). The difference between the revised 2006 estimate and the far lower rate previously estimated ( 34 per 1,000$)^{5}$ is therefore solely the result of the new methodology. However, this stability in the overall rate conceals an important positive change-that 16,475 safe, legal public-sector abortions were performed in Mexico City in $2009,{ }^{18}$ accounting for $14 \%$ of all abortions in the city.

\section{Differences by Region and State}

As we had hypothesized, estimated abortion rates varied by level of development (Table 2, page 61). The rate was highest in Region 1, the most developed of the six (54 abortions per 1,000 women). In the three regions with midrange development levels (Regions 2-4), abortion rates were much lower than in Region 1 and clustered in a narrow band (35-41 per 1,000). In Regions 5 and 6, the least developed of the group, rates were markedly lower than those elsewhere (26-27).

We also found wide variations among states within some regions (Table 3). In Region 2, for example, rates varied from 17 to 54. In eight of the region's 13 states, rates fell into a narrower range (29-46); however, rates were very low in Nuevo León (17) and Chihuahua (22), and high in Baja California Sur (50), Colima (50) and Mexico State (54)

State abortion rates in Region 4 also varied widely. Four of the six states had rates ranging from 29 to 40, but this region also contains the state with the highest abortion rate in the country (Tabasco-59 per 1,000) and the state with the second lowest rate (Yucatán-20 per 1,000).

By comparison, less variation was evident among the seven states in Region 3, where the abortion rate generally ranged from 33 (in Sinaloa, which borders the United States) to 44 (in Durango); one outlier state (Zacatecas)

*States were grouped into regions as follows: Region 1 (which includes $8 \%$ of all women aged 15-44) consists of Mexico City; Region 2 (43\% of women aged 15-44) consists of Aguascalientes, Baja California, Baja California Sur, Chihuahua, Coahuila, Colima, Jalisco, México, Morelos, Nuevo León, Quintana Roo, Sonora and Tamaulipas; Region 3 (14\%) comprises Durango, Guanajuato, Nayarit, Querétaro, Sinaloa, Tlaxcala and Zacatecas; Region 4 (16\%) consists of Campeche, Michoacán, Puebla, San Luis Potosí, Tabasco and Yucatán; Region 5 (9\%) contains Hidalgo and Veracruz; and Region 6 (10\%) consists of Chiapas, Guerrero and Oaxaca. 
had a rate of 51 . The range in rates between the two states in Region 5 was also relatively narrow (24-34). Rates were most homogenous in Region 6, where abortion rates fell within the narrow range of 25-27.

\section{Abortion Morbidity}

The treatment rate for abortion complications is affected by the riskiness of unsafe abortions (other things being equal, lower risk is associated with lower complication and treatment rates) and by women's access to medical care (better access is associated with more women obtaining care, resulting in a higher treatment rate). Depending on the balance between these factors, treatment rates for abortion complications may rise even if abortions become less risky, and a more developed region may have a higher treatment rate than a less developed region, even if abortions are safer.

Nationally, the rate of public-sector treatment for induced abortion complications was 5.9 cases per 1,000 women aged 15-44 (Table 3). This slight increase from the 1990 rate of 5.4 per 1,000 women was likely due to improvement in women's access to health care during the past two decades, ${ }^{5}$ in fact, it is possible that the riskiness of abortions decreased, but that the impact of the decline on the treatment rate was concealed by a larger change due to improved access to medical care. Consistent with this possibility, treatment rates were higher in the three most developed regions (6.2-6.7; Table 2) than in the three least-developed regions (4.8-5.2).

Variation among states in treatment rates was greatest in Region 2, where rates ranged from 3.6 to 10.2 per 1,000 women (Table 3). Rates were more uniform across states in Region 3, generally falling into a narrow range of 5.2 to 6.8; the exception was Zacatecas, which had a rate of 7.6. In Region 4, treatment rates for four of the six states again fell in a narrow band (4.3-5.9), and tended to be lower than those of states in Region 3, but Tabasco's rate was very high (8.7) and Yucatán's very low (2.9). States in Regions 5 and 6, the least developed in the country, generally had treatment rates of about 5.0 per 1,000 women; although abortion services in these regions tend to be less safe than those in other regions, the rates of treatment for abortion complications were relatively low, most likely because of poorer than average access to care.

\section{Abortion Incidence by Age}

Age-specific abortion rates showed an inverted J-shaped pattern (Figure 1). The national abortion rate rose from 44 per 1,000 women among 15-19-year-olds to 55 per 1,000 among 20-24-year-olds, and then declined steadily with age, reaching its lowest point among women aged 40-44 (15 per 1,000).

This age pattern also occurred at the regional level and, in most cases, at the state level (Figure 1 and Table 4 , page 64). However, six states showed a small variation on the pattern: In four states in Region 2 (Aguascalientes, Chihuahua, Coahuila and Nuevo Leon) and two states in

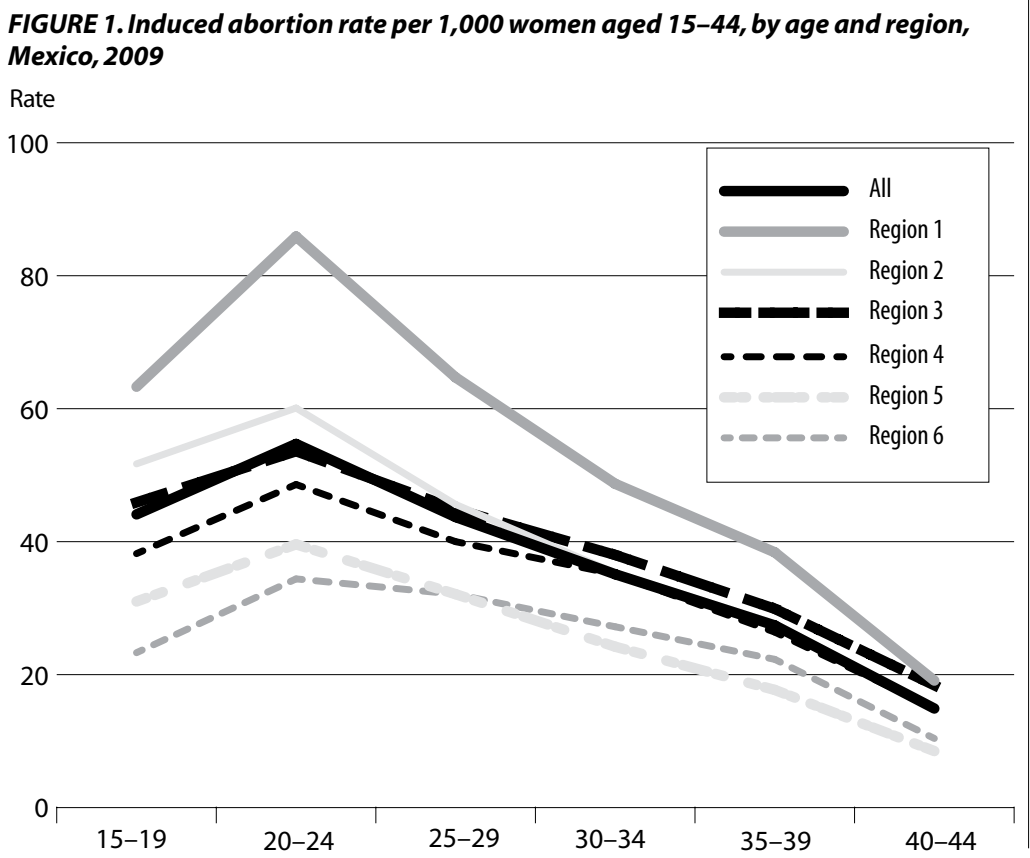

Region 3 (Nayarit and Sinaloa), adolescent women (those aged 15-19) had a higher abortion rate than women aged 20-24. The differences ranged from small (two per 1,000 in Nayarit) to moderate (12 per 1,000 in Coahuila).

For all age-groups, rates were higher in more developed regions than in less developed ones. For example, the abortion rate among women aged 20-24 was highest in Region 1 (86 per 1,000 women), but dropped to 49-60 in Regions $2-4$. Yet even the lowest rates in this age-group-40 in Region 5 and 34 in Region 6-were much higher than the rates for other age-groups in the respective regions.

The abortion rate was very high (more than 60 per 1,000) among adolescents in several states-Aguascalientes, Baja California Sur, Coahuila, Mexico City, Mexico State, Nayarit and Tabasco. The rate was a little lower (5060 per 1,000) in Colima, Morelos and Zacatecas. Women aged 20-24 had extremely high rates (at least 80 per $1,000)$ not only in Mexico City, but also in Baja California Sur, Mexico State and Tabasco; somewhat lower but still very high rates (60-75) were found in Coahuila, Colima, Nayarit and Zacatecas.

In the three states of Region 6 (Chiapas, Guerrero and Oaxaca), the patterns in abortion rates by age differed from those in the rest of the country: Rates were considerably lower than average across all age-groups and showed less variation by age. This is not surprising, given that the states in this region-especially Chiapas and Oaxaca-have higher fertility levels than other regions.

\section{DISCUSSION}

Examining abortion rates in Mexico offered a unique opportunity to improve an existing indirect estimation methodology because of the availability of state- and age-specific data on the number of women treated for induced abortion complications. By modifying the Abortion Incidence 
TABLE 4. Induced abortion rate by age, according to region and state, Mexico, 2009

\begin{tabular}{|c|c|c|c|c|c|c|}
\hline Region and state & $15-19$ & $20-24$ & $25-29$ & $30-34$ & $35-39$ & $40-44$ \\
\hline All & 44.1 & 54.7 & 43.7 & 35.1 & 27.4 & 14.9 \\
\hline Region 1 & 63.3 & 85.9 & 64.7 & 48.7 & 38.4 & 19.1 \\
\hline Federal District & 63.3 & 85.9 & 64.7 & 48.7 & 38.4 & 19.1 \\
\hline Region 2 & 51.7 & 60.1 & 45.6 & 35.3 & 27.7 & 15.0 \\
\hline Aguascalientes & 63.8 & 53.8 & 46.4 & 42.3 & 35.5 & 23.9 \\
\hline Baja California Sur & 74.2 & 81.1 & 56.3 & 38.7 & 26.0 & 13.6 \\
\hline Baja California & 40.2 & 46.8 & 32.7 & 21.9 & 15.9 & 9.7 \\
\hline Chihuahua & 34.1 & 26.4 & 25.6 & 17.4 & 12.8 & 8.7 \\
\hline Coahuila & 77.3 & 65.3 & 46.8 & 33.1 & 22.3 & 11.4 \\
\hline Colima & 54.1 & 72.5 & 64.4 & 45.3 & 36.2 & 19.8 \\
\hline Jalisco & 46.1 & 55.4 & 43.4 & 38.6 & 33.7 & 20.1 \\
\hline México & 63.3 & 85.9 & 64.7 & 48.7 & 38.4 & 19.1 \\
\hline Nuevo León & 29.8 & 22.7 & 14.9 & 14.3 & 13.2 & 7.5 \\
\hline Sonora & 49.6 & 57.1 & 40.4 & 31.5 & 23.3 & 11.0 \\
\hline Tamaulipas & 41.6 & 49.3 & 41.2 & 32.5 & 22.4 & 12.0 \\
\hline Morelos & 55.2 & 55.4 & 41.6 & 33.5 & 24.2 & 14.2 \\
\hline Quintana Roo & 49.4 & 56.0 & 37.1 & 24.6 & 20.5 & 12.5 \\
\hline Region 3 & 45.9 & 53.6 & 44.9 & 38.0 & 29.9 & 18.4 \\
\hline Durango & 46.6 & 57.5 & 52.7 & 48.7 & 33.1 & 19.7 \\
\hline Guanajuato & 40.2 & 49.8 & 41.4 & 36.8 & 32.6 & 20.8 \\
\hline Nayarit & 63.5 & 61.6 & 44.1 & 39.8 & 22.5 & 16.4 \\
\hline Querétaro & 49.5 & 58.9 & 50.3 & 37.8 & 32.0 & 22.2 \\
\hline Sinaloa & 49.2 & 45.5 & 37.6 & 29.7 & 19.4 & 9.9 \\
\hline Tlaxcala & 34.8 & 53.1 & 39.4 & 32.9 & 24.7 & 15.9 \\
\hline Zacatecas & 52.8 & 65.7 & 61.4 & 51.0 & 43.3 & 23.1 \\
\hline Region 4 & 38.2 & 48.6 & 40.0 & 35.1 & 26.4 & 15.0 \\
\hline Campeche & 41.2 & 57.9 & 48.0 & 31.5 & 25.5 & 9.7 \\
\hline Michoacán & 42.8 & 50.5 & 44.4 & 40.4 & 32.4 & 18.3 \\
\hline Puebla & 33.8 & 44.3 & 35.2 & 31.4 & 22.0 & 13.4 \\
\hline San Luis Potosí & 28.0 & 35.8 & 32.9 & 29.8 & 25.9 & 15.7 \\
\hline Tabasco & 70.5 & 90.3 & 65.2 & 54.7 & 36.1 & 16.9 \\
\hline Yucatán & 18.7 & 23.8 & 21.8 & 21.5 & 17.3 & 12.2 \\
\hline Region 5 & 31.0 & 39.6 & 32.1 & 24.2 & 17.7 & 8.5 \\
\hline Hidalgo & 38.8 & 50.7 & 39.5 & 31.5 & 23.5 & 10.6 \\
\hline Veracruz & 28.3 & 35.8 & 29.5 & 21.7 & 15.7 & 7.9 \\
\hline Region 6 & 23.3 & 34.4 & 32.1 & 27.2 & 22.3 & 10.4 \\
\hline Chiapas & 24.2 & 36.7 & 29.6 & 23.7 & 20.5 & 10.0 \\
\hline Guerrero & 23.4 & 29.7 & 32.3 & 27.6 & 24.2 & 9.8 \\
\hline Oaxaca & 22.0 & 35.3 & 35.3 & 31.4 & 23.0 & 11.4 \\
\hline
\end{tabular}

Note: Abortion rate is the number of abortions per 1,000 women aged 15-44.

Complications Method, we generated state-level estimates of abortion incidence that can provide important context in debates concerning abortion policies in the 31 states with restrictive laws. Estimates of age-specific abortion rates also can provide guidance to policymakers, because they help identify the women in each region and state (including the Federal District) who are most likely to have abortions, and toward whom the greatest efforts for prevention of unplanned pregnancies should be directed.

Nationally, an estimated 1,026,000 abortions were performed in Mexico in 2009, equivalent to an annual rate of 38 per 1,000 women aged $15-44$. The rate was largely stable between 2006 and 2009 (after adjustment for methodological changes), and was higher than the rate for Latin America as a whole (32 per 1,000 in 2008). ${ }^{22}$

Abortion incidence was higher in the more developed regions of the country than in the less developed ones, probably because women in these regions are more strongly motivated to have small families and to time their births. Moreover, regional variations were undoubtedly related to wide differences in socioeconomic conditions. For example, in Mexico City, where 54\% of women have had 10 or more years of schooling and $67 \%$ of working people live above the poverty line, the abortion rate was twice that in Region 6, where a much smaller proportion of women have had 10 years of education (27\%) and poverty is much more prevalent (only $28 \%$ of the working population is above the poverty line). ${ }^{13,23}$

In some regions, abortion rates varied widely among states, although for the most part we found the expected pattern of states with higher levels of development having higher abortion rates. A few extreme results revealed the limitations of available data; in particular, the sample of the Health Professionals Survey was not large enough nor widely enough distributed across the country to adequately represent conditions for all states. For example, two border states, Chihuahua and Nuevo León, had very low abortion rates, probably because many women in these states obtain abortions in the United States. Other outliers also have plausible explanations. Tabasco had the highest abortion rate in the country, which may be related to the rapid social and economic changes and high levels of internal migration occurring in this state. The very low abortion rate estimated for Yucatán might be explained by cultural differences that affect abortion incidence, such as that a large proportion of the population is Mayan or that the stigma against abortion may be much stronger in this state than elsewhere. More in-depth research is needed to understand whether results for states with very high or very low rates are real, or whether they are due at least in part to reporting or estimation issues.

Age-specific data on abortion in Mexico, which are available here for the first time, showed an inverted J-shaped pattern, both nationally and in all six regions; rates were elevated among adolescents, reached their highest levels among women aged 20-24 and steadily declined among older women. In addition, at every age, rates were much higher in more developed regions than in less developed ones. The age-specific pattern and level of abortion incidence in Mexico is consistent with historical patterns in developed countries. For example, in the United States, the abortion rate in 1990 was 39 per 1,000 among adolescents, peaked at 57 among 20-24-year-olds, fell to 34 among 25-29-year-olds and continued to decrease with age. ${ }^{24}$ Similarly, in 1995, the abortion rate in Estonia was 34 per 1,000 among adolescents, reached its highest levels among women aged 20-24 and 25-29 (87 each), and then declined to 64 among 30-34-year-olds and to still lower levels among older women. ${ }^{24}$ More recent data for the United States continue to show an age pattern similar to that currently found for Mexico, but at a much lower level: In 2008 , the U.S. abortion rate was 20 per 1,000 among adolescents, peaked at 40 per 1,000 among 20-24-yearolds, fell to 29 among 25-29-year-olds and continued to decline with age. ${ }^{25}$

The high rates of abortion in Mexico among women aged 15-24 may be related to a number of factors. The 
level of unmet need for contraception is very high among both married and unmarried sexually active young women. ${ }^{13}$ For example, in 2009, 27\% of married women aged 15-24 reported that they did not want a child soon but were not using any method of contraception (i.e., had an unmet need for contraception); the proportion who had an unmet need was similar among never-married women aged 15-24 who had been sexually active in the previous month. Furthermore, of the never-married, sexually experienced women aged 15-24 who had not been sexually active in the previous month, only $16 \%$ had ever used a modern method. ${ }^{26}$ In addition, given the strong stigma attached to premarital childbearing, pregnancy among the unmarried is very likely to lead to abortion. In Region 1 , the exceptionally high abortion rate among young women is likely influenced by the relatively lengthy interval (an average of six years) between first intercourse and first marriage; during this interval, which is longer in Region 1 than in other regions, women are at risk for unwanted pregnancy. ${ }^{13}$ Another factor that may contribute to high levels of unintended pregnancy and abortion among young women in Mexico is poor knowledge about contraception, a problem that highlights the need for comprehensive sex education, better counseling on how to use contraceptive methods correctly, and training to improve women's ability to negotiate effective contraceptive use with their partners. $^{13,23,27-34}$

The low incidence of abortion among women aged 35 or older, compared with that among younger women, may be explained in part by the former group's lower fecundity, higher levels of sterilization and (perhaps) lower levels of sexual activity-factors that result in low rates of pregnancy and unintended pregnancy and, consequently, of abortion as well.

One reason that women of all ages resort to abortion is the difficulty that they (and their partners) have in using contraceptives continuously and effectively. A qualitative study of women in Mexico City documented that participants faced many barriers in preventing unintended pregnancy and often used contraceptives only sporadically; despite their expressed desire to plan their births, reproduction essentially occurred "without a plan." 29

The 2009 data show that morbidity from unsafe abortion continues to threaten public health in Mexico. That year, approximately 159,000 women were treated at government facilities for complications of induced abortion; this is equivalent to 5.9 cases per 1,000 women aged 1544 , a rate very similar to that in $1990 .^{5}$ The Health Professionals Survey, which was carried out in 2007, found that an estimated one-third of Mexican women who had had clandestine abortions had used misoprostol; ${ }^{35}$ use of misoprostol began around 2000 in Mexico and has since increased steadily. ${ }^{35-37}$ In the short term, increased use of misoprostol may result in higher rates of hospitalization for abortion complications, because it may take several years before knowledge of how to use the drug correctly becomes widespread in a population. ${ }^{38}$ However, data from 1990, 2006 and 2009 indicate that the rate of abortion complications in Mexico has been stable during the past two decades. Because access to medical care has improved during this period, it is possible that, in real terms, treatment rates for induced abortion complications have declined. Although data are not available to parse out the factors that have contributed to abortion complications, the observed trend in treatment rates suggests, at a minimum, that the high level of misoprostol use has not increased the rate of abortion complications.

As expected, regional rates of hospitalization for abortion complications varied by development level, ranging from 4.8-5.1 cases per 1,000 in the least-developed regions to 6.7 per 1,000 in the most-developed region. Differences among states also were, to some extent, consistent with disparities in social and demographic factors. However, we found some notable differences from expected patterns. Among the factors that may explain interstate differences are unmeasured social, cultural and economic factors related to women's motivation to obtain an abortion; availability of low-risk clandestine abortion services; and women's ability to obtain postabortion services. Such factors may also influence rates of treatment for postabortion complications and, to some degree, differences in the age pattern of abortion rates.

\section{Limitations}

Although it has been widely used during the past 20 years, the Abortion Incidence Complications Method, like any indirect estimation technique, has limitations, which have been discussed in detail elsewhere., ${ }^{5,7}$ For some input variables, the method relies on assumptions and on estimates based on health professionals' perceptions. As a result, it provides only an estimate of abortion incidence, not an exact measure. This is adequate to identify large differences between areas or groups; however, any smaller differences that occur may not be meaningful. To estimate state- and age-specific abortion rates, we made additional modifications, which required additional assumptions and adjustments. Although state-level data were available for all components of the Mexican health system, age-specific data were unavailable for some smaller subsystems. Thus, we had to estimate the distribution of treatment cases by age in these missing smaller subsystems by applying the age distribution seen in the larger subsystems.

Another limitation was the need to rely on multipliers that were based on 2007 data and calculated only for the four large areas. Although we expect that using the 2007 multipliers for 2009 estimates is acceptable at the national and regional levels, it is likely that we did not capture some important interstate differences in multipliers, and this would help explain some of the unexpected results at the state level. To allow us to better estimate multipliers for individual states or groups of states, the sample size for the Health Professionals Survey would need to be much greater and drawn from a larger number of areas across the country. 


\section{Policy Implications}

Our findings indicate that induced abortion is common in all states of Mexico. Women in more developed regions and young women are especially motivated to avoid unwanted or mistimed births, as the elevated abortion rates in these subgroups suggest. This is compelling evidence that all states in Mexico need to improve and strengthen family planning services, by such strategies as providing comprehensive counseling to couples about the full range of contraceptive options, emphasizing the importance of consistent use and helping women switch to another method if they experience side effects from their current contraceptives. Young people have a pressing need for better access to contraceptive information and services that are specifically oriented to their circumstances, to enhance their ability to prevent unintended pregnancies. Moreover, postabortion contraceptive counseling and services are essential, particularly given the large number of women treated each year for complications of abortion.

The changes in Mexico City's abortion law have given women in this part of the country an essential reproductive health right: access to safe, legal abortion services. However, abortion remains highly restricted in the rest of the country. These new state- and age-specific estimates of the incidence of abortion and treatment for abortion complications may inform and stimulate debate within states, especially now that some states have tightened restrictions on abortion. In addition, this study provides clear evidence of the dimension and severity of the problem of unsafe abortion, which may aid stakeholders as they advocate for action by state governments, which are responsible for funding reproductive health services, developing and implementing guidelines and standards of health care, and enacting and enforcing abortion laws.

\section{REFERENCES}

1. World Health Organization (WHO), The Prevention and Management of Unsafe Abortion: Report of a Technical Working Group, Geneva, 12-15 April 1992, Geneva: WHO, 1993.

2. Rossier C, Estimating induced abortion rates: a review, Studies in Family Planning, 2003, 34(2):87-102

3. WHO, Unsafe Abortion: Global and Regional Estimates of the Incidence of Unsafe Abortion and Associated Mortality in 2008, sixth ed., Geneva: WHO, 2011

4. Aahman E and Shah I, Generating national unsafe abortion estimates: challenges and choices, in: Singh S, Remez L and Tartaglione A, eds., Methodologies for Estimating Abortion Incidence and AbortionRelated Morbidity: A Review, New York: Guttmacher Institute, 2010, pp. 13-22.

5. Juarez F et al., Estimates of induced abortion in Mexico: What's changed between 1990 and 2006? International Family Planning Perspectives, 2008, 34(4):158-168.

6. Singh S and Wulf D, Estimated levels of induced abortion in six Latin American countries, International Family Planning Perspectives, 1994, 20(1):4-13

7. Singh S, Prada E and Juarez F, The abortion incidence complications method: a quantitative technique, in: Singh S, Remez L and Tartaglione A, eds., Methodologies for Estimating Abortion Incidence and Abortion-Related Morbidity: A Review, New York: Guttmacher Institute, 2010, pp. 71-97.
8. Grupo de Información en Reproducción Elegida (GIRE), El Proceso de Despenalización del Aborto en la Ciudad de México, Mexico City: GIRE, 2008.

9. Secretaría de Salud, Sistema Nacional de Información en Salud (SINAIS), Health sector morbidity and SAEH, 2000 to 2009, <http:// dgis.salud.gob.mx/cubos>, accessed July 15, 2011

10. Secretaría de Salud, SINAIS, Publicaciones: Boletín de Información Estadística, volumen III: servicios otorgados y programas sustantivos, <http://www.sinais.salud.gob.mx/publicaciones/ index. html>, accessed July 15, 2011

11. Secretaría de Salud, SINAIS, Emergency room database, 2000 to 2009, available at <http://dgis.salud.gob.mx/cubos>, accessed July $15,2011$.

12. Juarez F et al., Appendix to Estimates of induced abortion in Mexico: What's changed between 1990 and 2006? <http://www. guttmacher.org/pubs/ifpp/appendix/3404.pdf>, accessed Aug. 20, 2011.

13. Juarez F et al., Las Necesidades de Salud Sexual y Reproductiva de las Adolescentes en México: Retos y Oportunidades, New York: Guttmacher Institute, 2010

14. Schiavon R, Ipas, Mexico City, personal communication, Nov. 10, 2010 .

15. Bongaarts J and Potter R, Fertility, Biology and Behavior: An Analysis of the Proximate Determinants, New York: Academic Press, 1983

16. Harlap S, Shiono PH and Ramcharan S, A life table of spontaneous abortions and the effects of age, parity, and other variables, in: Porter IH and Hook EB, eds., Human Embryonic and Fetal Death, New York: Academic Press, 1980, pp. 145-158.

17. Consejo Nacional de Población (CONAPO), Encuesta Nacional de Dinámica Demográfica, 2006, Mexico City: CONAPO, 2006.

18. Secretaría de Salud del Distrito Federal, Agenda Estadística 2009, Mexico City: Secretaría de Salud del Distrito Federal, 2010

19. Rutstein $\mathrm{SO}$, Change in the desired number of children: a crosscountry cohort analysis of levels and correlates of change, DHS Analytical Reports, Calverton, MD, USA: Macro International, 1998, No. 9

20. Woldemicael G, Reproductive intentions and fertility in Ethiopia and Eritrea: trends and prospects for the future, Stockholm Research Reports in Demography, Stockholm, Sweden: Stockholm University Department of Sociology, 2008, No. 4.

21. CONAPO, Índices de Marginación, 2005, Mexico City: CONAPO, 2006 .

22. Sedgh $G$ et al., Induced abortion: incidence and trends worldwide from 1995 to 2008, Lancet, 2012, 379(9816):625-632.

23. Juarez F et al., Barreras para la Maternidad Segura en México, New York: Guttmacher Institute, 2010.

24. Henshaw S et al., eds., Readings on Induced Abortion, Volume 2: A World Review 2000, New York: Guttmacher Institute, 2001.

25. Jones RK and Kavanaugh ML, Changes in abortion rates between 2000 and 2008 and lifetime incidence of abortion, Obstetrics $\varepsilon$ Gynecology, 2011, 117(6):1358-1366.

26. Special tabulations of data from the Encuesta Nacional de la Dinámica Demográfica 2009.

27. Amuchástegui Herrera A and Rivas Zivy M, Clandestine abortion in Mexico: a question of mental as well as physical health, Reproductive Health Matters, 2002, 10(19):95-102.

28. Erviti J, El Aborto Entre Mujeres Pobres: Sociología de la Experiencia, Cuernavaca, Mexico: Universidad Nacional Autónoma de México 2005.

29. Juarez F and Bayer AM, 'Without a plan' but 'keeping on track': views on contraception, pregnancy and abortion in Mexico City, Global Public Health, 2011, 6(Suppl. 1):S90-S110.

30. Lamas M and Bissell S, Abortion and politics in Mexico: 'contex is all,' Reproductive Health Matters, 2000, 8(16):10-23. 
31. Mendoza D et al., 35 años de planificación familiar en México, in: CONAPO, ed., La Situación Demográfica de México 2009, Mexico City: CONAPO, 2009, pp. 39-52.

32. Menkes $C$ and Suarez L, Educación sexual, conocimiento sobre la biología de la reproducción y funcionamiento de métodos anticonceptivos en Guanajuato, in: Stern C, ed., Adolescentes en México: Investigación, Experiencias y Estrategias para Mejorar Su Salud Sexual y Reproductiva, Mexico City: El Colegio de México and Population Council, 2008, pp. 233-254.

33. Menkes $C$, Prácticas sexuales de hombres y mujeres adolescentes en México desde la perspectiva de una salud reproductiva, unpublished dissertation, Cuernavaca, Mexico: Centro de Investigación y Docencia en Humanidades del Estado de Morelos, 2009.

34. Zúñiga E, La situación demográfica de los jóvenes, in: Stern C, ed., Adolescentes en México: Investigación, Experiencias y Estrategias para Mejorar su Salud Sexual y Reproductiva, Mexico City: El Colegio de México and Population Council, 2008, p. 27-57.

35. Special tabulations of data from the 2007 Health Professionals Survey.

36. Wilson KS et al., Misoprostol use and its impact on measuring abortion incidence and morbidity, in: Singh S, Remez L and Tartaglione A, eds., Methodologies for Estimating Abortion Incidence and Abortion-Related Morbidity: A Review, New York: Guttmacher Institute, 2010, pp. 191-201.

37. Pick $S$ et al., Pharmacists and market herb vendors: abortifacient providers in Mexico City, in: Mundigo A and Indriso C, eds., Abortion in the Developing World, London: Zed Books, 1999, pp. 293-310.

38. Blanchard K et al., Misoprostol alone-a new method of medical abortion? Journal of the American Medical Women's Association, 2000, 55(3 Suppl.):189-190.

\section{RESUMEN}

Contexto: Debido a que en México las entidades federativas individuales son las que determinan las leyes de aborto, las cuales generalmente son altamente restrictivas, los datos a nivel estatal son esenciales para que los formuladores de políticas tomen decisiones informadas. Además, las estimaciones de abortos especificas por edad son necesarias ante la preocupación social acerca del riesgo de embarazos no deseados y abortos en las mujeres jóvenes.

Métodos: El Método de Estimación de Aborto por Complicaciones, un enfoque ya establecido diseñado para obtener estimaciones de aborto nacionales y a nivel de grandes regiones, se extendió para producir por vez primera estimaciones para grupos de edad y para estados. Los datos usados incluyen las estadísticas gubernamentales sobre las pacientes postaborto $y$ las estimaciones de profesionales de la salud en relación con las complicaciones de aborto. Los estados se clasificaron en seis regiones según su nivel de desarrollo.

Resultados: En 2009, la tasa de aborto en México fue de 38 abortos por 1,000 mujeres en edades de 15-44. La tasa fue de 54 por 1,000 en la Región 1 (Ciudad de México), la región más desarrollada; 35-41 por 1,000 en las Regiones 2, 3 y 4, que son moderadamente desarrolladas; y 26-27 en las Regiones 5 y 6 , que son las menos desarrolladas. A nivel de estado, las tasas de aborto inducido y de tratamiento por complicaciones postaborto, en general, son consistentes con el nivel de desarrollo del estado, aunque surgieron algunas excepciones. Las tasas de aborto específicas por edad alcanzaron al nivel máximo en mujeres de 20-24 años, y disminuyeron con la edad; este patrón se observó a nivel nacional, regional y en la mayoría de los estados.
Conclusión: Fue posible avanzar el Método de Estimación de Aborto por Complicaciones para obtener datos específicos por estado y por edad. El aborto inseguro es común en todos los estados de México, y su incidencia es especialmente alta en las mujeres jóvenes de 15-24 años, lo que sugiere la necesidad de mejores servicios de planificación familiar y atención postaborto.

\section{RÉSUMÉ}

Contexte: Généralement fort restrictives, les lois qui régissent l'avortement au Mexique sont déterminées à l'échelle de chaque état; des données au niveau de l'état sont par conséquent essentielles à la prise de décisions stratégiques éclairées. De plus, des estimations relatives à l'avortement en fonction de l'âge sont nécessaires étant donné la préoccupation sociétale concernant le risque de grossesse non désirée et d'avortement parmi les jeunes femmes.

Méthodes: Approche établie pour l'obtention d'estimations nationales et régionales générales, la méthode AICM d'évaluation de l'incidence de l'avortement en fonction des complications traitées a été étendue pour produire les premières estimations par groupes d'âge et états. Les données incluent les statistiques gouvernementales sur les patientes après avortement et les estimations des professionnels de la santé concernant les complications de l'avortement. Les états sont classifiés en six régions suivant leur niveau de développement.

Résultats: En 2009, le taux d'avortement général du Mexique était de 38 pour mille femmes âgées de 15 à 44 ans, soit 54 pour mille dans la Région 1 (Mexico - région la plus développée), 35 à 41 pour mille dans les Régions 2, 3 et 4 modérément développées et 26 à 27 pour mille dans les Régions 5 et 6 les moins développées. Au niveau des états, les taux d'incidence de l'avortement et de traitement des complications de l'IVG s'alignent généralement sur le niveau de développement, avec quelques exceptions toutefois. Les taux d'avortement en fonction de l'âge atteignent leur plus haut niveau parmi les femmes âgées de 20 à 24 ans, pour diminuer ensuite régulièrement avec l'âge. La tendance est observée à l'échelle nationale, régionale et dans la plupart des états.

Conclusion: L'extension de la méthode AICM en vue de l'obtention de données à l'échelle de l'état et en fonction de l'âge est faisable. L'avortement non médicalisé est courant dans tous les états du Mexique, en particulier parmi les femmes de 15 à 24 ans, laissant entendre un besoin d'amélioration des services de planification familiale et après avortement.

\section{Acknowledgments}

The authors thank Sandra G. Garcia and Akinrinola Bankole for reviewing early drafts of the article, and Isaac Maddow-Zimet for his help in data analysis. In addition, they thank Sandra G. Garcia and Claudia Diaz Olavarrieta for their assistance in obtaining data, as well as the staff of the Dirección General de Información en Salud, who provided guidance on the use of their data. The authors are also grateful to the Population Council-Mexico for their financial support of the study.

Author contact:fjuarez@colmex.mx 